\title{
A NEW VARIANT FORM OF HEPATIC GLYCO- GENOSIS WITH ACID MALTASE DEFICIENCY
}

\author{
Nobuyuki NinomiYa, ${ }^{1}$ Takanori Terashima, ${ }^{1}$ Teruo Iwamasa, ${ }^{2}$ \\ and Ichiro MATSUDA ${ }^{1}$ \\ ${ }^{1}$ Department of Pediatrics, and ${ }^{2}$ Department of Pathology, Kumamoto \\ University Medical School, Kumamoto 860, Japan
}

\begin{abstract}
Summary A 6-year-old Japanese girl with acid maltase deficiency showed unusual clinical features of the disease; doll-like face, short stature, hepatomegaly, proximal renal tubular acidosis, but no muscular weakness or hypotonia. Diagnosis of acid maltase deficiency was made based on the following findings of the liver tissue obtained by surgical biopsy: increased glycogen content, presence of glycogenosome, and reduction and some kinetic abnormalities of acid maltase. The enzyme deficiency was also found in the peripheral white blood cells using anti-human acid maltase anti-serum. These findings suggest that the patient had a new variant form of glycogen storage disease with acid maltase deficiency.
\end{abstract}

\section{INTRODUCTION}

Acid maltase deficiency; glycogen storage disease type II has been observed in infants, children and adults. Generalized muscle weakness, enlargement of tongue, liver and heart, and death mostly in the first year of life are hallmark of the disease in infancy (Howell and Williams, 1982). In childhood type of the disease the symptoms are primarily muscle weakness and hypotonia, and survival is possible into the second decade of life (Howell and Williams, 1982). This report describes a female child with acid maltase deficiency, who presented unusual clinical features, suggesting a new clinical variant of the disease.

\section{CASE REPORT}

The patient was a 6-year-old Japanese girl and the first child of unrelated parents. Her birth weight was $2,800 \mathrm{~g}$ after a 40 week gestation. Her development was normal. Head control was possible at 4 months and she walked at 1 
year and 2 months of age. Her hepatic enlargement was noticed by a physician at the age of 4 years. On admission, she was 6 years old, and her body weight and height were $15.6 \mathrm{~kg}(-1.4 \mathrm{SD})$ and $102.3 \mathrm{~cm}(-2.7 \mathrm{SD})$, respectively. She had doll-like facial features (Fig. 1). The liver edge descended $7 \mathrm{~cm}$ below the right costal margin. Macroglossia, cardiomegaly, muscle weakness, hypotonia, muscle pain and muscle contracture were absent. Abdominal radiogram revealed enlarged kidneys. No abnormalities were observed in the examination of peripheral blood counts, blood glucose, serum triglyceride, free fatty acid, lactic acid, uric acid, creatinine, aldolase, SGOT and SGPT, and in urine analysis including myoglobin excretion. Blood gas analysis revealed mild metabolic acidosis: $\mathrm{pH} 7.34, \mathrm{pCO}_{2}$ $25.5 \mathrm{mmHg}, \mathrm{pO}_{2} 78 \mathrm{mmHg}, \mathrm{HCO}_{3}^{-} 13.7 \mathrm{mEq} /$ liter and base excess -10.0 . Under this condition urine $\mathrm{pH}$ was 6.2 and serum electrolytes were normal except for the elevated chloride level $(111 \mathrm{mEq} /$ liter $)$. ECG, EEM and chest radiogram were all normal. According to the method of Fernandes et al. (1974) screening test for glycogen storage disease was performed as follows; after an oral administration of glucose $(2 \mathrm{~g} / \mathrm{kg})$, both blood glucose and serum lactate were measured by the conventional methods and the results obtained were similar to those of controls. Oral galactose loading test also showed normal reaction in terms of blood glucose. Fasting glucagon test $(0.03 \mathrm{mg} / \mathrm{kg})$ and postprandial glucagon test were carried out at different date, and blood sugar level were elevated normally but not highly at the both tests. Since we could not give a possible diagnosis in the patient from these observations, liver specimen was obtained by surgical biopsy with parents' permission for further studies. A follow-up observation was made until 10 years of age and her school performance including physical exercise did not have any trouble.

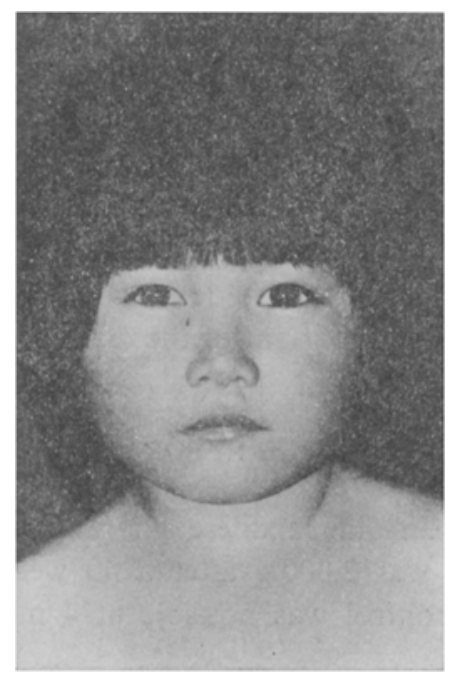

Fig. 1. Facial features of the patient. 


\section{METHODS}

Histolochemical and ultrastructural examination of liver. Surgically obtained liver specimen was processed for histochemistry and electronmicroscopy. The histochemical stains included hematoxylin and eosin, and periodic acid-Schiff (PAS).

Biochemical examination of liver and white blood cells. Using conventional methods, glycogen content (Steifer et al., 1950) and activities of the following enzymes in liver were measured: glucose-6-phosphatase (Hers et al., 1966), phosphorylase (Sutherland and Wosilait, 1956), debranching enzyme (Van Hoff et al., 1967), and maltase, in which maltase activity was determined using both the maltose (Hers, 1963) and the 4-methyl-umbelliferyl-glucoside (Salafsky and Naddler, 1973) as substrates. Several kinetic studies of maltase including heat stability $\left(55^{\circ} \mathrm{C}\right.$ for 20 and $40 \mathrm{~min}$ ), inhibiting effect of turanose $(0.03 \mathrm{~mm})$ (Marry et al., 1978) and apparent $K_{\mathrm{m}}$ value at pH 4.0 (Marry et al., 1978) for maltose were also studied. For measurement of white blood cell maltase, white blood cells were isolated by sedimentation in dextran and cell lysates were prepared with distilled water, followed by freezing and thawing five times. The enzyme activity was measured using 4-methyl-umbelliferyl derivative alone as substrate (Dreyfus et al., 1980). The enzyme activity was measured in the presence and absence of anti-human-hepatic acid maltase antiserum, which was prepared by the method described previously (Ninomiya et al., 1983).

Renal acidification and bicarbonate loading tests. Ammonium chloride and bicarbonate loading tests were performed by the method described previously (Matsuda et al., 1975).

\section{RESULTS}

\section{Microscopic findings of liver}

Microscopic examinations of the liver revealed cytoplasm of the parenchimal cells to be swollen and filled with glycogen. Hepatic lobular architecture was not distorted. Under an electronmicroscopy, large amounts of glycogen were found which were freely dispersed in the cytoplasm of the liver cells. Most conspicuous feature was the presence of numerous glycogenosome with variable sizes in which glycogen was segregated (Fig. 2). The nuclei were free of glycogen and other organelle were essentially normal.

\section{Biochemical findings of liver}

The results obtained are listed in Table 1. The patient's liver contained an increased amount of glycogen. Enzyme activities were all within normal limit except for the maltase, which was partially reduced at $\mathrm{pH} 4.0$ measured using maltose as a substrate. This observation was further confirmed by an enzyme profile as shown in Fig. 3, where 4 methylumbelliferyl derivative was used as a substrate. Compared to control, patient's maltase was different in the $K_{\mathrm{m}}$ value and the inhibiting effect of turanose but was similar in heat stability (Table 2). 


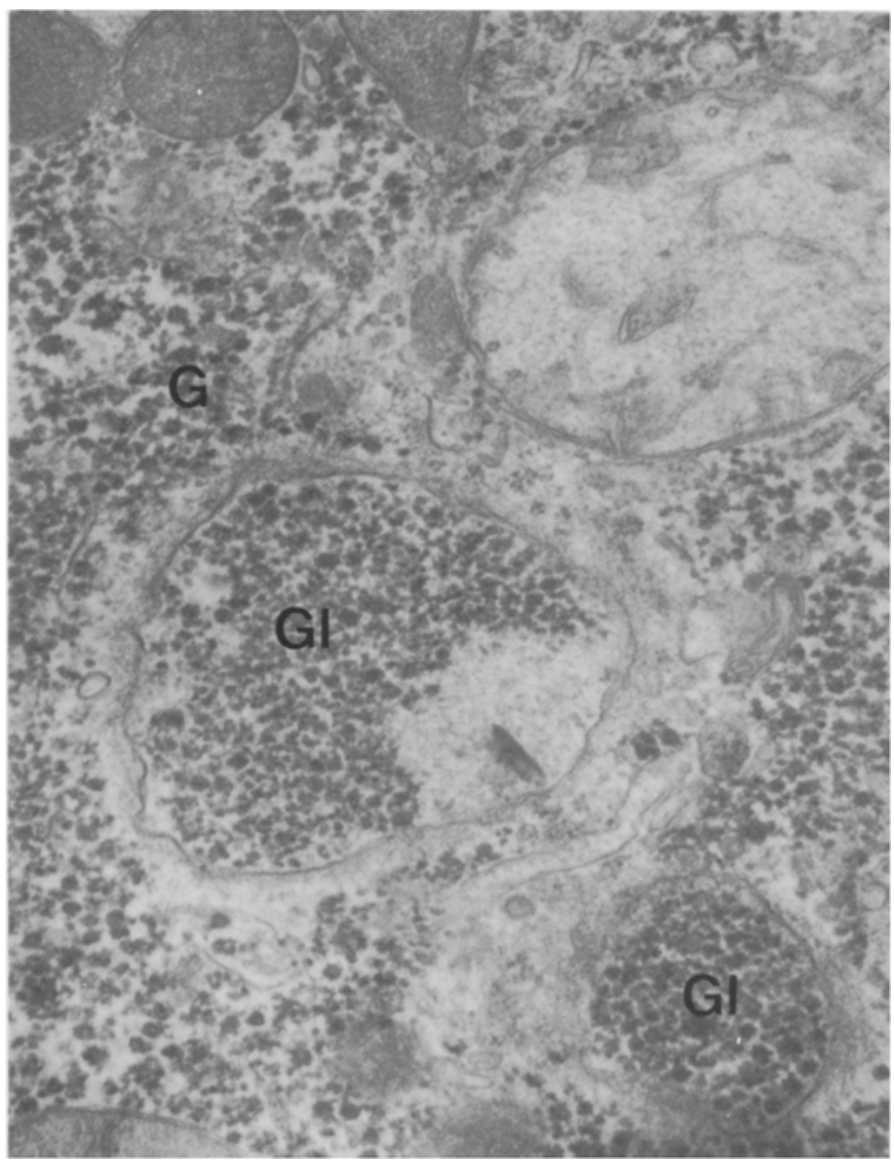

Fig. 2. Electronmicrograph of liver. Note the presence of glycogenosomes. $(\times 22,500)$ $\mathrm{G}$, glycogen; G1, glycogenosome.

Table 1. Glycogen content and enzyme activities of liver.

\begin{tabular}{|c|c|c|}
\hline & Patient & Control \\
\hline Glycogen content ( $\mu \mathrm{M} / \mathrm{mg}$ protein) & 124.9 & $40.9 \pm 9.9 \quad(n=4)$ \\
\hline Glucose-6-phosphatase ( $\mu \mathrm{M} / \mathrm{mg}$ protein $/ \mathrm{min})$ & 2.4 & $2.47 \pm 0.21 \quad(n=4)$ \\
\hline Phosphorylase ( $\mu \mathrm{M} / \mathrm{mg}$ protein/min) & 40.0 & $37.1 \pm 3.2 \quad(n=4)$ \\
\hline Amino 1,6 -glucosidase $(\mu \mathrm{M} / \mathrm{mg}$ protein $/ \mathrm{min})$ a & 26.2 & $23.4 \pm 3.3 \quad(\mathrm{n}=4)$ \\
\hline$(\mathrm{cpm} / \mathrm{mg} \text { protein } / \mathrm{hr})^{b}$ & 52.2 & $66.2 \pm 19.9 \quad(n=4)$ \\
\hline $\begin{array}{l}\text { Maltase ( } \alpha \text {-glucosidase) at } \mathrm{pH} 4.0 \\
\quad(\mathrm{mg} \text { maltose hydrolysed } / \mathrm{mg} \text { protein } / \mathrm{hr})^{\mathrm{c}}\end{array}$ & 250 & $\pm 70.7 \quad(\mathrm{n}=4)$ \\
\hline
\end{tabular}

Jpn. J. Human Genet. 


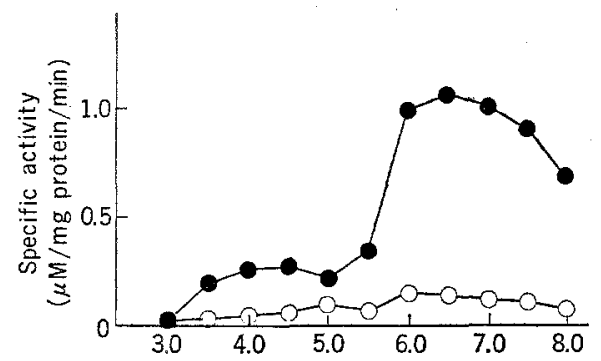

Fig. 3. $\mathrm{pH}$ profile of acid $\alpha$-glucosidase activity of liver. control sample; $O$, patient sample.

Table 2. Characterization of liver maltase. ${ }^{2}$

Heat stability at $55^{\circ} \mathrm{C}$ (residual activity)

$\begin{array}{lcc} & 20 \mathrm{~min} & 40 \mathrm{~min} \\ \text { Control } & 100 \% & 100 \% \\ \text { Patient } & 99 \% & 99 \%\end{array}$

Turanose inhibition $(0.03 \mathrm{~mm}) \mathrm{c}$

Control

Patient

Apparent $K_{\mathrm{m}}$ value (at $\mathrm{pH} 4.0$ )

Control

Patient
$35.6 \pm 7.5 \%(\mathrm{n}=4)$

$18.6 \%$

$8.0 \mathrm{mM}$

$8.9 \mathrm{~b}$

a Maltose as substrate. 'Cited from the data by Murray et al.. c 4-Methylumbelliferyl- $\alpha$-glucoside as substrate.

Table 3. $\alpha$-Glucosidase in peripheral white blood cells at $\mathrm{pH} 4.0$.a

\begin{tabular}{lccc}
\hline & $\begin{array}{c}\text { Without } \\
\text { anti-serum } b\end{array}$ & $\begin{array}{c}\text { With } \\
\text { anti-serum } b\end{array}$ & $\%$ of reduction \\
\hline Control $\left(10^{-2} \mu \mathrm{M} / \mathrm{mg}\right.$ protein $\left./ \mathrm{min}\right)$ & 0.70 & 0.25 & 64.3 \\
Patient $\left(10^{-2} \mu \mathrm{M} / \mathrm{mg}\right.$ protein $\left./ \mathrm{min}\right)$ & 0.45 & 0.40 & 11.0 \\
\hline
\end{tabular}

a 4-Methyl-umbelliferyl- $\alpha$-glucoside as substrate. $b$ Anti-human hepatic acid maltase anti-serum.

White blood cell maltase

Enzyme activity at $\mathrm{pH} 4.0$ was reduced in the patient's white blood cells, and after incubation with anti-acid maltase-serum, the reduction of activity was $64.3 \%$ in the control and $11.1 \%$ in the patients (Table 3). This observation indicated that the acid maltase in the patient's white blood cells was impaired.

\section{Acidification and bicarbonate loading tests}

Urinary acidification, ammonium and titratable acid excretion were within nor- 
mal limits. Threshold point and the maximum reabsorption rate of bicarbonate were $19.0 \mathrm{~mm} /$ liter (control, $23 \mathrm{~mm} /$ liter), and $1.9 \mathrm{~mm} / 100 \mathrm{ml} \mathrm{GF}$ (control $2.8 \mathrm{~mm}$ / $100 \mathrm{ml} \mathrm{GF}$ ), respectively, suggesting the presence of proximal renal tubular acidosis (Rodorigues-Sariano and Edelman, 1969).

\section{DISCUSSION}

Histological and biochemical evidences of increased glycogen content, presence of glycogenosome found by electronmicroscopic examination and reduced acid maltase activity in the liver tissue indicated that this patient had hepatic glycogenosis with acid maltase deficiency. Kinetic analysis of the enzyme showed similar heat stability but different $K_{\mathrm{m}}$ value and inhibiting effect of turanose, compared with the control, suggesting the presence of a mutant enzyme. A pH profile of hepatic maltase of the patient is comparable to those of infantile and childhood type of the disease (Angelini and Engel, 1972). In addition, both the acid and the neutral maltase activities were reduced. A reduced acid maltase activity in white blood cells was confirmed using anti-human hepatic acid maltase anti-serum (Dreyfus and Poenau, 1980). Because of the limited amount of sample, immunochemical study of liver maltase was not done. The present case will be classified as a childhood type of the disease, based on her age of onset of the disease. In affected children of acid maltase deficiency, organomegaly is not consistently present (Engel et al., 1973), whereas muscle weakness seems to be main and consistant clinical feature (Howell et al., 1982). Therefore, her clinical features of doll-like face, short stature, hepatomegaly, proximal renal tubular acidosis and absence of muscle weakness and hypotonia were unusual in childhood type of the disease, and rather fit to the glycogen storage disease of type I. Screening test by Fernandes et al. (1974) did not give us a possible diagnosis. Therefore, we have performed liver biopsy but not muscle biopsy simultaneously. After the diagnosis was given to the patient, further examination of her muscle was intended. However, since her muscle function has been normal during the follow-up study, an informed consent was not obtained for muscle biopsy. Similarly to the present case, an marked hepatomegaly but normal muscle structure, which was first suspected as glycogen storage disease type I, has been recorded in a 2 year and 6 month-old girl with acid maltase deficiency, but she had hypotonia and further details were uncertain (Hers and van Hoof, 1968). Renal tubular acidosis has been observed in type I (Howell and Williams, 1982) and type III glycogen storage disease (Cohen and Frieman, 1979) but not in others. The present case might be the first one with renal tubular dysfunction associated with acid maltase deficiency to the best of our knowledge. Enlarged nephrogram possibly due to glycogen storage in the patient and/or disturbed glycogen metabolism in the kidney may be related to this tubular dysfunction, although the detailed mechanism remains to be clarified. 
Acknowledgments This study was supported by Grand-in-Aid for Scientific Research from the Ministry of Education, Science and Culture of Japan (584802555, Matsuda).

\section{REFERENCES}

Angelini, C. and Engel, A.G. 1972. Comparative study of acid maltase deficiency. Arch Neurol. 26: 344-349

Cohen, J. and Frieman, M. 1979. Renal tubular acidosis associated with type III glycogenosis. Acta Pediatr. Scand. 68: 779-782

Dreyfus, J.C. and Poenau, L. 1980. White blood cells and the diagnosis of $\alpha$-glucosidase deficiency. Pediatr. Res. 14: 342-344

Engel, A.G., Gomez, M.R., Seybold, M.E., and Lambert, E.H. 1973. The spectrum and diagnosis of acid maltase deficiency. Neurology 23: 95-106

Fernandes, J., Koster, J.F., Grose, W.F.A., and Sorgedarger, N. 1974. Hepatic phosphorylase deficiency. Its differentiation from other hepatic glycogenosis. Arch. Dis. Child. 49: 186191

Hers, H.G. 1963. a-Glucosidase deficiency in generalized glycogen storage disease (Pompe's disease) Biochem. J. 86: 11-16.

Hers, H.G. and van Hoof, F. 1966. Enzymes of glycogen degradation in biopsy material. In Methods in Enzymology, VIII, Neufeld, E.F. and Ginsburg, V., eds., Academic Press, New York and London, pp. 525-532

Hers, H.G. and van Hoof, F. 1968. Glycogen-storage disease; Type II and type VI glycogenosis. In Carbohydrate Metabolism and It's Disorders, Vol. 2, Dickens, F., Randle, R.J., and Whelan, W.J., eds., Academic Press, London, New York, pp. 151-160. eds., Academic Press, London, New York, pp. 151-160.

Howell, R.R. and Williams, J.C. 1982. The glycogen storage disease. In The Metabolic Basis of Inherited Disease, Stanbury, J.B., Wyngarden, J.B., Fredrickson, D.S., Goldstein, J.L., and Brown, M.S., eds., McGraw-Hill Book Company, New York, pp. 141-166.

Marray, A.K., Brown, B.I., and Brown, D.H. 1978. The molecular heterogeneity of purified human liver lysosomal a-glucosidase (Acid a-glucosidase). Arch. Biochem. Biophys. 185: 511524

Matsuda, I., Takekoshi, Y., Shida, N., Fujieda, K., Nagai, B., Arashima, S., and Oka, Y. 1975. Renal tubular acidosis and skeletal demineralization in patients on long term anticonvulsant therapy. J. Pediatr. 82: 202-205

Ninomiya, N., Matsuda, I., Fukuda, S., Iwamasa, T., and Osame, M. 1983. Immunohistochemical determination of acid $\alpha$-glucosidase in the muscle of Pompe's disease (II 6 Type). Histochem. J. 15: 601-606.

Rodorigues-Sariano, J. and Edelman, C.M. 1969. Renal tubular acidosis. Ann. Rev. Med. 20: $363-382$

Salafsky, I.R. and Naddler, H.L. 1973. Deficiency of acid-alpha glucosidase in the urine of patients with Pompe's disease. J. Pediatr. 82: 294-297

Steifer, S., Dayton, S., Novic, B., and Muntwyer, E. 1950. The estimation of glycogen with anthron reagent. Arch. Biochem. Biophys. 25: 191-200.

Sutherland, E.W. and Wosilait, W.D. 1956. The relationship of epinephrine and glycogen to liver phosphorylase: I. Liver phosphorylase; preparation and properties. J. Biol. Chem. 218: 458468

Van Hoff, F. and Hers, H.G. 1967. The subgroups of type III glycogenosis. Europ. J. Biochem. 2: 265-270.

Vol. 29, No. 2, 1984 